\title{
The Influence of Verse on Cognitive Processes: A Psycholinguistic Experiment
}

\author{
Tatyana Skulacheva
}

Institute of Russian Language of the

Russian Academy of Sciences, Russia

skulacheva@yandex.ru

(1) 0000-0002-0679-6084

\section{Alexander Kostyuk}

Institute of Russian Language of the Russian Academy of Sciences, Russia kostyuk.ae@gmail.com (D) 0000-0002-8104-4245

\section{Emil Latypov}

Russian University for Humanities, Russia latypow.emil@gmail.com

\author{
Natalia Slioussar \\ Higher School of Economics / \\ St. Petersburg State University, Russia \\ slioussar@gmail.com \\ (1D) 0000-0003-1706-6439
}

\author{
Anna Lipina \\ Russian University for Humanities, Russia \\ anna.lipina.94@mail.ru

\section{Varvara Koroleva} \\ Russian University for Humanities, Russia \\ varyak1999@gmail.com
}

\begin{abstract}
Modern psycho- and neurolinguistics use standards of precision typical of the natural sciences. As verse scholarship also bases its standards on those of the natural sciences, it can be combined fruitfully with the natural sciences, including neuroscience. This may ultimately allow us to answer the fundamental question of how verse and prose are processed in the brain. In this paper, we present the preliminary results of our project that aims to uncover how verse's effects on cognitive processes compare to those of prose. We conducted 3 experiments with 110 informants who were native speakers of Russian between 18 and 55 years old. These experiments had the same design but involved different stimulus texts and groups of informants $(40+40+30)$. Informants are known to slow down their reading considerably if they detect a textual error. Our aim was to compare the reading times for different verse and prose fragments when they contained errors and when they were error-free. We found that errors in verse remain undetected while the same errors are easily perceived in a corresponding prose text. The observation of this phenomenon in all three experiments is important proof of its validity. We suggest that prose and verse differently activate two ways of processing information in the brain: the first way is logical and relies on critical thinking including error detection, while the second is associative and depends on mental imagery rather than sequential logic.
\end{abstract}




\section{Introduction}

Modern psycho- and neurolinguistics use standards of precision typical of the natural sciences. As the standards of verse studies also reflect those of the natural sciences (Yarxo 2006), it can be paired productively with natural science disciplines, including neuroscience. This may eventually allow us to answer the key question of how verse and prose are each processed in the brain. In this paper, we present the preliminary results of our project that aims to uncover how verse's effects on cognitive processes compare with those of prose.

In our previous studies, we collected a vast amount of data on the linguistic structure of verse (Skulacheva 1996, 2004, 2014, 2016; Skulacheva and Buyakova 2010; Skulacheva and Kostyuk 2018, 2019). The main point of these investigations was to identify the most stable regularities in verse irrespective of language, period, versification system, literary trend or individual style. In other words, we were interested in the properties that presumably characterize verse as such as opposed to prose. At the time of writing, we have found a number of such regularities. However these do not refer to meter, rhyme, stanzas, alliteration, enjambment or any other parameter readily associated with verse form. Regular meter, rhyme and stanzaic structure are often absent from irregular types of verse. Alliteration and enjambment are never regular even in modern classical verse. Nevertheless it turns out that several aspects of verse structure are present in all verse types across different languages, periods and literary trends, including the most vaguely organized free verse.

In this regard, parataxis significantly prevails over hypotaxis in verse works. This has been shown for Russian, French, English, German and Spanish verse and prose (Skulacheva and Buyakova 2010; Skulacheva and Kostyuk 2019, 2020). Secondly, monotonous intonation with no distinct descent at the end of the sentence is characteristic of verse-the diapason is twice as narrow in verse as it is in prose. These generalizations have been made regarding Russian verse and prose (Kostyuk 2017; Krivnova et al. 2020; Skulacheva and Kostyuk 2020), and we have recently obtained comparable data for English. A similar phenomenon has been observed by Yanko $(2010,2015)$ with regard to Russian and Arabic prayer. Thirdly, the context of verse often precludes the choice of a single meaning of a polysemous word while the prose context facilitates the choice of a particular meaning. A number of other regularities have also been found. These work at different linguistic levels and seem to be aimed at hampering comprehension. But why compose a text and, at the same time, make it difficult to understand? Our hypothesis is that all of the linguistic mechanisms mentioned above serve to impede sequential logical thinking. As a result, other processing strategies (and specifically those that are parallel, associative and rely on mental imagery) become more prominent.

We came across many examples where logical and critical thinking had apparently been suppressed by the structure of verse, and as a result, readers consistently missed even serious logical paradoxes and ambiguities. These included a famous poem by A. Blok "V goluboj, dalekoj spalenke..." ("In a distant blue room...”). The poem describes a room in which we find a young woman and a child. The child is in bed, and the verb used to refer to him is opochil, which in 
Russian may mean both "fell asleep" and "died". Normally, the context shows unambiguously which of the two meanings should be chosen. But Blok's context is so subtly suggested that it is hard to be sure which of the two meanings is correct. After discussing this poem with different audiences, we found that they tended to divide into two almost equal groups: those who were sure that the author was depicting a cozy room that held a woman he loved and a sleeping child, and those who believed that the child was dead and the poem described a tragedy. It was only when the text was retold in prose that both audiences realized that a different interpretation was possible and they had not fully understood the text.

We wished, however, to proceed beyond examples to testable hypotheses. How could we prove that information in verse is processed so differently that mistakes and ambiguities obvious in prose remain undetected? To do this, we designed a series of psycholinguistic experiments. The current paper presents the first statistically valid evidence that mistakes of different kinds are not noticed in verse whereas they are easily detected in prose. They prove that mistakes of different kinds are not noticed in verse whereas they are easily detected in prose.

\section{Methods}

Many experimental studies in linguistics rely on measuring reading time. One basic observation recorded since at least the early 1980s (Just and Carpenter 1980; Just, Carpenter, and Wooley 1982) is that various types of errors cause the reader to slow down. To estimate how much the reader slows down and to determine whether the effect is statistically significant, the average reading time for a textual fragment is compared when it contains a particular error versus when it is error-free. More recent studies have shown that the extent of this effect depends on how easily the error is detected: errors which are intuited as more serious and noticed more easily (as measured independently via error detection rates) lead to an extension of reading time. In contrast, errors that tend to go unnoticed barely slow down the reader. Studies of subject-verb agreement errors may serve as an example (e.g. Clifton et al. 1999; Dillon et al. 2013; Pearlmutter et al. 1999; Wagers et al. 2009).

In our study, we relied on these observations. Our aim was to compare reading times for different verse and prose fragments when they did and did not contain errors. We conducted 3 experiments in which a total of 110 informant volunteers took part. These experiments had the same design but involved different stimulus texts and different groups of informants $(40+40+30)$ - the goal was to check whether the results would be replicated despite these differences. The informants were Russian native speakers from 18 to 55 years old who were not aware of the real focus of the experiments.

Since we hypothesized that the failure to detect mistakes in verse was due to the suppression of logical thinking, it was important not to activate logical thinking through the design of our experiments. A direct question like "Did you notice a mistake in this text?" might neutralize a suppressive effect by drawing 
the reader's attention to the text's logic. The informants were therefore told that we were studying the moods in which people preferred to read different poems and prose fragments. At the beginning of the experiment, they were also asked to complete a questionnaire. In addition to regular questions about their age, gender and education, they were asked about their current mood. The mood classification for this purpose was taken from a previous study (Proxorov 2011). After they read each piece of verse or prose, the informant was asked if the fragment had resonated with their mood.

At the same time, the reading time data that we were interested in were obtained as follows: the experiments were conducted online on the Ibexfarm platform (Drummond et al. 2016). Each informant read a verse or prose fragment and then pressed a button to proceed to the questions about the fragment. At this point, the program recorded their reading time. Later we compared the reading times for fragments that did and did not contain a mistake for both verse and prose. The informant was instructed to read the text fragments and answer questions about them. In each case, the experiment started with two "filler" fragments (see below) so that the informant could get used to the procedure.

The stimulus texts (i.e. the texts for the experiments) were prepared as follows: we chose four-line fragments from different types of Russian versethese ranged from classical meters to dolnik to verse libre. We also prepared prose counterparts of the fragments. The prose variants were kept as close to the original texts as possible in lexis and syntax. Only obvious meter, rhyme and word order characteristics typical of verse were changed. One error was then introduced in each text, preferably in the second or third line of a four-line verse fragment, and the same error was used in the prose variant. The errors were of the following types:

\section{Lexical-semantic}

(a) three instead of two for the count and the countess - three of them instead of two of them

(b) up instead of down (where "underneath" is the intended meaning) and vice versa - climb up to the gulley/cellar instead of walk down to the gulley/cellar and step down to the very top instead of step up to the very top

2. Syntactic-semantic

(a) trees of branches instead of branches of trees

(b) the beard pours from the water instead of the water pours from the beard (of a drowned man in A. Pushkin's poem "Utoplennik").

Below we provide some examples that show 1 ) the original verse text; 2) its prose counterpart; 3) the verse text with an error; and 4) the prose counterpart with an error.

1.1 My tajnobrachnye cvety...

Nikto ne znal, chto my lyubili, 
Chto aromat lyubovnoj pyli

Vdoxnuli dvoe - ya i ty!

1.2 My - tajnobrachnye cvety. Nikto ne znal o nashix chuvstvax, o tom, chto dvoe - ya i ty - vdoxnuli lyubvi aromat.

("We are like secret flowers. Nobody knew that we loved one another, that the two of us-you and I-inhaled the perfume of love."-Original verse fragment and its prose counterpart)

1.3 My tajnobrachnye cvety...

Nikto ne znal, chto my lyubili,

Chto aromat lyubovnoj pyli

Vdoxnuli troe - ya i ty!

1.4 My - tajnobrachnye cvety. Nikto ne znal o nashix chuvstvax, o tom, chto dvoe - ya i ty - vdoxnuli lyubvi aromat.

("We are like secret flowers. Nobody knew that we loved one another, that the three of us-you and I-inhaled the perfume of love."-Verse and prose fragments with an error introduced: three instead of two)

2.1 O, tol'ko by domoj dojti! Pyatnadcat'

Minut xod'by. Pyat' ulic minovat'.

Po lestnice na samyj verx podnyat'sya

I v dver' uslovnym stukom postuchat'...

2.2 O, dojti by tol'ko domoj! Pyatnadcat' minut xod'by. Minovat' pyat' ulic. Podnyat'sya na samyj verx po lestnice i postuchat' uslovnym stukom $\mathrm{v}$ dver'.

("Oh, if I could only get home! It is a 15-minute walk. Cross five streets. Climb the stairs up to the very top and knock on the door with a secret knock."-Original verse fragment and its prose counterpart)

$2.3 \quad$ O, tol'ko by domoj dojti! Pyatnadcat'

Minut xod'by. Pyat' ulic minovat'.

Po lestnice na samyj verx spustit'sya

I v dver' uslovnym stukom postuchat'...

$2.4 \quad$ O, dojti by tol'ko domoj! Pyatnadcat' minut xod'by. Minovat' pyat' ulic. Spustit'sya na samyj verx po lestnice i postuchat' uslovnym stukom v dver'.

("Oh, if I could only get home. It is a 15-minute walk. Cross five streets. Climb down the stairs to the very top and knock on the door with a secret knock."-Verse and prose fragments with an error introduced: climb down instead of climb up)

3.1 Pod oknom shumyat i mechutsya

Vetki klenov i berez...

Bez ulybok my vstrechalisya

I rasstanemsya bez slez. 
3.2 Pod oknom mechutsya i shumyat vetki klenov $i$ berez...My bez ulybok vstrechalis'i bez slez rasstanemsya.

("Under the window the branches of the maples and birches move and rustle. We met without smiling and will part without tears."-Original verse fragment and its prose counterpart)

3.3 Pod oknom shumyat i mechutsya

Kleny vetok i berez...

Bez ulybok my vstrechalisya

I rasstanemsya bez slez.

3.4 Pod oknom mechutsya i shumyat kleny vetok $i$ berez... My bez ulybok vstrechalis' i bez slez rasstanemsya.

("Under the window the maples of the branches and birches move and rustle. We met without smiling and will part without tears."-Verse and prose fragments with an error introduced: maples of the branches instead of branches of the maples)

4.1 Iz-za tuch luna katitsya -

Chto zhe? Golyj pered nim:

$S$ borody voda struitsya,

Vzor otkryt i nedvizhim.

4.2 Luna katitsya iz-za tuch - chto zhe? Pered nim golyj: s borody struitsya voda, otkryt i nedvizhim vzglyad.

("The moon appears from behind the clouds. What is this? Someone naked is before him, water pours from the beard, the eyes are open and fixed.”-Original verse fragment and its prose counterpart)

4.3 Iz-za tuch luna katitsya -

Chto zhe? Golyj pered nim:

Boroda s vody struitsya,

Vzor otkryt i nedvizhim.

4.4 Luna katitsya iz-za tuch - chto zhe? Pered nim golyj: boroda s vody struitsya, otkryt i nedvizhim vzglyad.

("The moon appears from behind the clouds. What is this? Someone naked is before him, the beard pours from the water, the eyes are open and fixed."-Verse and prose fragments with an error introduced: the beard pours from the water instead of the water pours from the beard)

We also prepared a number of "filler” texts, i.e. four-line verse fragments and their prose versions. These fragments contained no errors. Each experiment involved a total of sixteen (16) fragments: eight (8) stimulus fragments of which four (4) contained errors (the experimental condition) and four (4) were errorfree (the controlled condition; see below) as well as eight (8) filler fragments. As a result, the share of fragments with errors was relatively small. In this way, we also avoided drawing too much attention to the errors. 


\begin{tabular}{llc}
\hline Text type & Condition & Average reading time (sec) \\
\hline prose & control $^{1}$ & $6.6(1.5)^{2}$ \\
& experimental $^{1}$ & $7.9(1.9)$ \\
& filler & $6.6(2.0)$ \\
poetry & control & $7.8(2.0)$ \\
& experimental & $7.7(1.7)$ \\
& filler & $7.3(1.8)$ \\
\hline
\end{tabular}

Table 1: Average reading times for prose and verse fragments with and without an error (Experiment I, 40 informants)

We used the "Latin square" principle, which is often applied in experiment design. This involved comparing texts with and without an error on the one hand, and verse and prose texts on the other. The group of texts in each experiment served as a control for the other two. In each of the three experiments, the informants were divided into four groups. Each group received its own set of texts so that a text presented to one group with an error was shared error-free with another group.

1. 4 verse texts from set I with errors +4 verse texts from set II without errors +8 verse fillers

2. 4 verse texts from set II with errors +4 verse texts from set I without errors +8 verse fillers

3. 4 prose texts from set I with errors +4 prose texts from set II without errors +8 prose fillers

4. 4 prose texts from set II with errors +4 prose texts from set I without errors +8 prose fillers

Groups of informants received either verse or prose fragments. If verse did suppress logical thinking, we did not want to turn this mechanism on and off by mixing verse and prose fragments.

\section{Results}

We analyzed reading times for the fragments. In all three experiments, reading times that exceeded the mean plus three standard deviations (per condition) were excluded as outliers. As a result, a very small percentage of the data was excluded (this never exceeded 6\%). Table 1 shows the average reading times for texts with and without an error for both verse and prose fragments in Experiment I.

1 Control condition: original texts with no errors; experimental condition: original texts with an error introduced.

2 The standard deviation from the mean is given in parentheses. 


\begin{tabular}{llc}
\hline Text type & Condition & Average reading time (sec) \\
\hline prose & control & $10.6(1.5)$ \\
& experimental & $12.9(1.7)$ \\
& filler & $11.6(1.6)$ \\
poetry & control & $11.2(2.1)$ \\
& experimental & $10.8(1.8)$ \\
& filler & $10.7(1.9)$ \\
\hline
\end{tabular}

Table 2: Average reading times for prose and verse fragments with and without an error (Experiment II, 40 informants)

\begin{tabular}{llc}
\hline Text type & Condition & Average reading time (sec) \\
\hline prose & control & $9.3(1.4)$ \\
& experimental & $11.2(1.5)$ \\
\multirow{4}{*}{ poetry } & filler & $10.6(1.6)$ \\
& control & $10.4(1.5)$ \\
& experimental & $10.2(1.5)$ \\
& filler & $9.8(1.4)$ \\
\hline
\end{tabular}

Table 3: Average reading times for prose and verse fragments with and without an error (Experiment III, 30 informants)

We used RM ANOVAs to estimate whether the differences between the experimental and control conditions were statistically significant. Fragment reading time was treated as the dependent variable. According to this statistical analysis, the difference between the conditions was statistically significant for prose $(F(1,192)=3.69, p=0.05)$ but not for verse $(F(1,182)=0.02, p=0.88)$. This means that errors in prose were noticed and caused a significant slowdown, while in verse they remained undetected. The same pattern was found in Experiment II (Table 2).

The difference in reading times for the experimental and control conditions was statistically significant for prose $(F(1,150)=4.47, p=0.04)$ but not for verse $(F(1,150)=0.11, p=0.75)$. We again saw a significant slowing of the reading time for prose, which means that errors were noticed; in contrast, in verse, they remained undetected. The same picture was observed in Experiment III (Table 3).

For the prose texts, the difference between the experimental and control conditions was statistically significant $(F(1,109)=4.99, p=0.03)$, while for the verse ones, it was not $(F(1,112)=0.21, p=0.88)$. Again, errors in prose caused a considerable slowdown but this was not the case for verse. This shows that errors were discovered in the former but not in the latter. The observation of the same general trend in all three experiments is important proof of its validity.

We have recently completed another experiment that suggests that the same phenomenon applies when reading Turkish verse and prose with and without errors. We have selected Russian and Turkish verse as data points relatively dis- 
tant from one another in order to prove that the influence comes from the verse structure itself irrespective of verse type, language type and cultural traditions. The Russian verse used in our experiments includes syllabic-accentual and non-classical verse derived from the syllabic-accentual system. Moreover, the Russian language is inflectional. The Turkish verse is syllabic, and the Turkish language is agglutinative. Russian and Turkish cultural traditions significantly differ. Still, our experiments suggest that in both cases, the effect of verse on cognitive processes differs from that of prose in the same way.

\section{Conclusion}

Our findings show that errors in verse remain undetected while the same errors are easily discovered in a prose counterpart text. We suggest that prose and verse differently activate two ways of processing information in the brain; the first way is logical and relies on critical thinking including error detection, while the second is associative and depends on mental imagery rather than sequential logic.

\section{Acknowledgments}

The study was enabled by RFBR grant 19-012-00534.

\section{References}

Clifton, Charles Jr., Lyn Frazier, and Patricia Deevy (1999). "Feature manipulation in sentence comprehension”. In: Rivista di Linguistica 11, pp. 1139.

Dillon, Brian, Alan Mishler, Shayne Sloggett, and Colin Phillips (2013). "Contrasting intrusion profiles for agreement and anaphora: Experimental and modeling evidence”. In: Journal of Memory and Language 69.2, pp. 85-103. DoI: 10.1016/j.jml.2013.04.003.

Drummond, Alex, Titus von der Malsburg, Michael Yoshitaka Erlewine, and Mahsa Vafaie (2016). Ibex farm. URL: https://github.com/addrummond/ibex.

Just, Marcel A. and Patricia A. Carpenter (1980). "A Theory of Reading: From Eye Fixations to Comprehension”. In: Psychological Review 87, pp. 329-354. DOI: 10.1037/0033-295X.87.4.329.

Just, Marcel A., Patricia A. Carpenter, and Jacqueline D. Wooley (1982). "Paradigms and processes in reading comprehension”. In: Journal of Experimental Psychology: General 3, pp. 228-238. Dor: 10.1037//0096-3445.111.2.228.

Kostyuk, Alexander Edmundovich (2017). "Prosodiya stroki v russkom stixe". In: Trudy instituta Russkogo yazyka imeni V.V.Vinogradova 14, pp. 27-41. 
Krivnova, Olga Fedorovna and Alexander Edmundovich Kostyuk (2020). "Ramochnaya tonal'naya konstrukciya v foneticheskoj strukture stixa i prozy”. In: Vaprosy yazykoznaniya: Megasbornik nanostatej. Sb. st. kyubileyu $V$. A. Plungyana. Ed. by Andrej Aleksandrovich Kibrik, Kseniya Pavlovna Semenova, Dmitrij Vladimirovich Sichinava, Sergej Georgievich Tatevosov, and Anna Yur' evna Urmanchieva. Moskva: Buki-Vedi, pp. 86-98.

Pearlmutter, Neal J., Susan M. Garnsey, and Kathryn Bock (1999). “Agreement Processes in Sentence Comprehension”. In: Journal of Memory and Language 41.3, pp. 427-456. DoI: 10.1006/jmla.1999.2653.

Proxorov, Aleksandr Oktyabrinovich, ed. (2011). Psixologiya sostoyanij. Moskva: Cogito-center.

Skulacheva, Tatyana Vladimirovna (1996). "Lingvistika stixa: struktura stixotvornoj stroki”. In: Slavyanskij stix: stixovedenie, lingvistika i poe'tika. Ed. by Mixail Leonovich Gasparov and Tatyana Vladimirovna Skulacheva. Moskva: Nauka, pp. 18-23.

Skulacheva, Tatyana Vladimirovna (2004). "Stix i proza: semanticheskie razlichiya”. In: Slavyanskij stix VII: lingvistika i struktura stixa. Ed. by Mixail Leonovich Gasparov and Tatyana Vladimirovna Skulacheva. Moskva: Yazyki slavyanskoj kul'tury, pp. 167-178.

Skulacheva, Tatyana Vladimirovna (2014). "Verse and Prose: A Linguistic Approach”. In: Poetry and poetics: a centennial tribute to Kiril Taranovsky. Ed. by Barry P. Sherr, James Bailey, and Vida T. Johnson. Bloomington (Indiana): Slavica, pp. 239-248.

Skulacheva, Tatyana Vladimirovna (2016). "Struktura stixa i ego vospriyatie". In: Sed'maya mezhdunarodnaya konferenciya po kognitivnoj nauke. Ed. by Aleksandrov Yurij Iosifovich and Anoxin Konstantin Vladimirovich. Moskva: Institut psixologii RAN, pp. 545-546.

Skulacheva, Tatyana Vladimirovna and Mariya Valeryevna Buyakova (2010). "Stix i proza: sochinenie i podchinenie". In: Voprosy yazykoznaniya 2, pp. 3754.

Skulacheva, Tatyana Vladimirovna and Alexander Edmundovich Kostyuk (2018). "Stix: lingvisticheskie mexanizmy i ix funkcii". In: Vos'maya mezhdunarodnaya konferenciya po kognitivnoj nauke. Tezisy dokladov. Ed. by Andrej Konstantinovich Krylov and Valerij Dmitrievich Solov' ev. Moskva: Institut psixologii RAN, pp. 930-932.

Skulacheva, Tatyana Vladimirovna and Alexander Edmundovich Kostyuk (2019). "Verse and Prose: Linguistics and Statistics". In: Quantitative Approaches to Versification. Ed. by Petr Plecháč, Barry Paul Scherr, Tatyana Vladimirovna Skulacheva, Helena Bermúdez-Sabel, and Robert Kolár. Prague: ICL CAS, pp. 245-254.

Skulacheva, Tatyana Vladimirovna and Alexander Edmundovich Kostyuk (2020). "Lingvisticheskie osobennosti stixa i ix funkcii". In: Vestnik Volgogradskogo gosudarstvennogo universiteta. Seriya 2, Yazykoznanie 19.3, pp. 155-168. Dor: 10.15688/jvolsu2.2020.3.14.

Wagers, Matthew W., Ellen F. Lau, and Colin Phillips (2009). "Agreement attraction in comprehension: Representations and processes”. In: Journal of Memory and Language 61.2, pp. 206-237. DoI: 10.1016/j.jml.2009.04.002. 
Yanko, Tatyana Evgenyevna (2010). "Prosodiya predlozhenij so «snyatoj» illokutivnoj siloj”. In: Komp'yuternaya lingvistika i intellektual'nye texnologii: Tr. Mezhdunar. konf. po komp'yuternoj lingvistike i ee prilozheniyam "Dialog2010” 9.16, pp. 609-621.

Yanko, Tatyana Evgenyevna (2015). "Lingvisticheskie texnologii analiza zvuchashhego poe'ticheskogo teksta”. In: Kognitivnye issledovaniya yazyka 23 , pp. 174-183.

Yarxo, Boris Isaakovich (2006). Metodologiya tochnogo literaturovedeniya: Izbrannye trudy po teorii literaturovedeniya. Moskva: Languages of the Slavic Cultures. 